\title{
Metabolic Alterations in Cancer Cells and the Emerging Role of Oncometabolites as Drivers of Neoplastic Change
}

\author{
Zhengqiu Zhou ${ }^{1}$, Elochukwu Ibekwe ${ }^{1}$ and Yevgen Chornenkyy ${ }^{1,2, *}$ \\ 1 College of Medicine, University of Kentucky, 800 Rose St., Lexington, KY 40506, USA; \\ zhengqiu.zhou@uky.edu (Z.Z.); e.ibekwe@uky.edu (E.I.) \\ 2 Department of Molecular and Cellular Biochemistry, University of Kentucky, Lexington, KY 40536, USA \\ * Correspondence: yevchornenkyy@uky.edu
}

Received: 1 December 2017; Accepted: 14 January 2018; Published: 17 January 2018

\begin{abstract}
The mitochondrion is an important organelle and provides energy for a plethora of intracellular reactions. Metabolic dysregulation has dire consequences for the cell, and alteration in metabolism has been identified in multiple disease states-cancer being one. Otto Warburg demonstrated that cancer cells, in the presence of oxygen, undergo glycolysis by reprogramming their metabolism-termed "aerobic glycolysis". Alterations in metabolism enable cancer cells to gain a growth advantage by obtaining precursors for macromolecule biosynthesis, such as nucleic acids and lipids. To date, several molecules, termed "oncometabolites", have been identified to be elevated in cancer cells and arise from mutations in nuclear encoded mitochondrial enzymes. Furthermore, there is evidence that oncometabolites can affect mitochondrial dynamics. It is believed that oncometabolites can assist in reprogramming enzymatic pathways and providing cancer cells with selective advantages. In this review, we will touch upon the effects of normal and aberrant mitochondrial metabolism in normal and cancer cells, the advantages of metabolic reprogramming, effects of oncometabolites on metabolism and mitochondrial dynamics and therapies aimed at targeting oncometabolites and metabolic aberrations.
\end{abstract}

Keywords: mitochondria; oncometabolites; cancer; metabolic re-programming; aerobic glycolysis; mitochondrial dynamics

\section{Aerobic Glycolysis in Normal and Cancer Cells}

Glucose is a vital molecule, providing energy for the cell and acting as a starting point for many reactions. Aerobic glycolysis begins when glucose enters the cell via insulin dependent or independent mechanisms, using the glucose transporter (GLUT) isoform membrane transporters [1]. In the cytoplasm, glucose undergoes glycolysis and generates pyruvate that is subsequently converted to acetyl-CoA by the pyruvate dehydrogenase (PDH) complex, located in the mitochondria. Acetyl-CoA will then act as a substrate for the first step of the tricarboxylic acid (TCA) cycle [2]. Mitochondria are biosynthetic and bioenergetic organelles, which function by utilizing molecules from the cytoplasm to facilitate the TCA cycle, urea cycle, ketogenesis, fatty acid oxidation, the electron transport chain, and synthetize important cellular macromolecules (amino acids, nucleotides, lipids, etc.) (Figure 1) [3]. Mitochondria contain a small $16 \mathrm{~kb}$ DNA genome, encoding tRNA, rRNA, and proteins essential for cellular respiration. Out of the 37 genes, 13 participate in the electron transport chain (Supplementary Table S1) [4]. Cells have hundreds of mitochondria, and typically, the number of mitochondria per cell is tissue-dependent. For instance, tissues like cardiomyocytes have more mitochondria than squamous epithelial cells [5]. Since each cell depends on mitochondria, diseases affecting this organelle have devastating consequences and affect multiple organ systems, like the nervous system, heart, 
and muscles [6]. As mitochondrial DNA is maternally-inherited, some mitochondrial diseases are caused by maternal inheritance of mutated mitochondria or loss-of-function (LOF) mutations in mitochondrial genes.

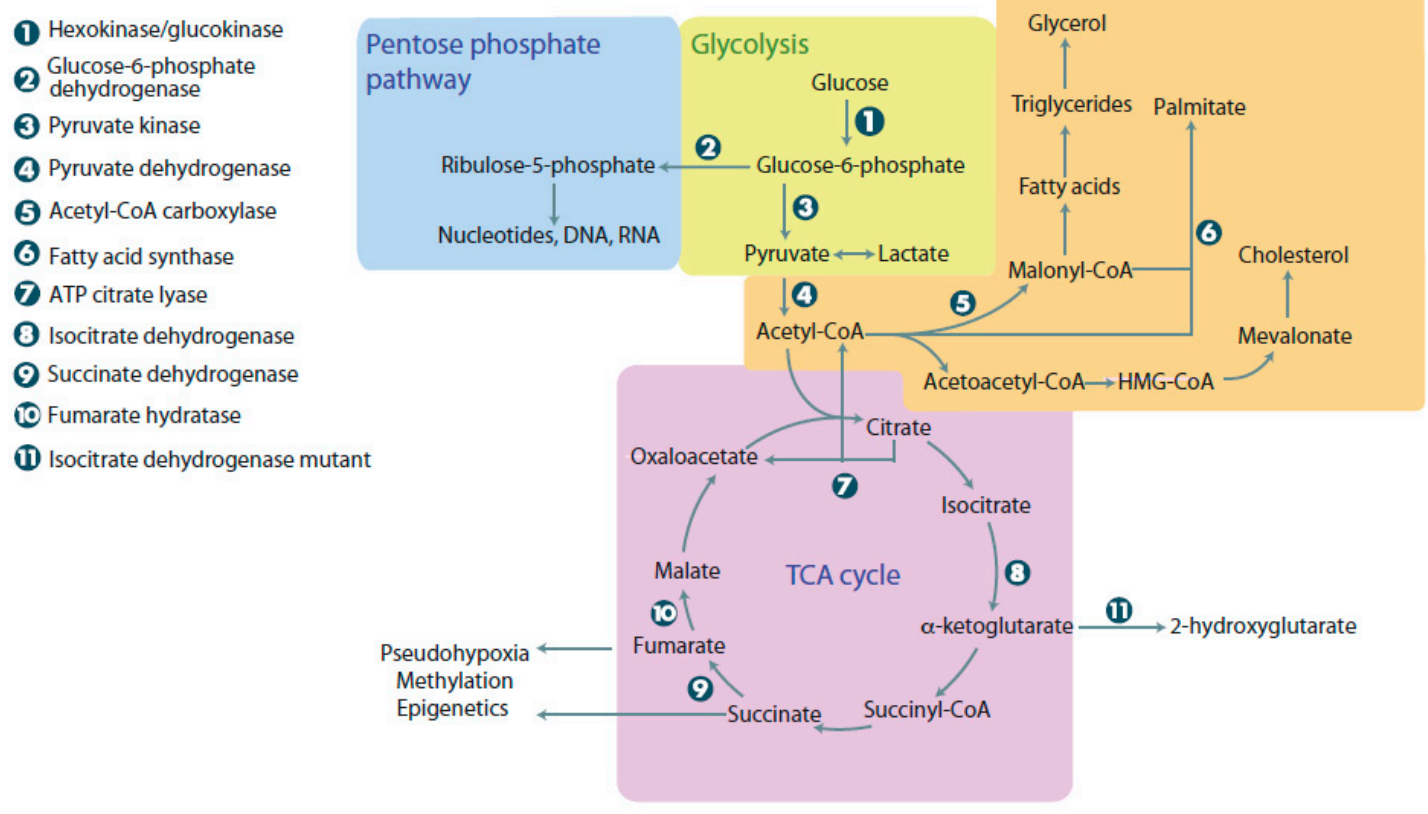

Figure 1. Metabolic pathways in normal and cancer cells. When glucose enters cells, it undergoes glycolysis, linking it to the pentose phosphate pathway, lipid metabolism, and the tricarboxylic acid (TCA) cycle. The pentose phosphate pathway can be used to make nucleotides, DNA, and RNA. Lipid metabolism is used for energy and synthesis of membrane components. The TCA cycle provides cells with intermediates for the electron transport chain and links many other metabolic reactions that occur in the cell. Cancer cells with mutations in metabolic enzymes have increased levels of 2-hydroxyglutarate, succinate, and malate, resulting in adverse cellular outcomes. ATP: Adenosine triphosphate.

Cancer is theorized to be a somatic disease, arising from activating mutations in oncogenes and LOF mutations in tumor suppressor genes [7]. In contrast to the somatic mutation theory of cancer, Otto Warburg and others hypothesized that cancer is a metabolic disease, with respiratory insufficiency being the origin tumorigenesis [8-10].

While each theory provides a unique perspective on tumorigenesis, the reality is likely more complicated, and it may be that both mechanisms work in tandem. Geou-Yarh Liou et al., demonstrated, using in vitro and in vivo models of pancreatic adenocarcinoma, that K-Ras ${ }^{\mathrm{G} 12 \mathrm{D}}$ induced mitochondrial flux produces high levels of reactive oxygen species (ROS) that subsequently increase the activity of NF- $\mathrm{NB} 1$ and $\mathrm{NF}-\kappa \mathrm{B} 2$, leading to up regulation of epidermal growth factor receptor (EGFR) signaling [11]. In addition to K-Ras mutations, mitochondrial function is also influenced by the Phosphoinositide 3-kinase/Protein kinase B (PKB/AKT)/mechanistic target of rapamycin (PI3K/PKB(AKT)/mTOR) pathway. Makinoshima et al., demonstrated that levels of glucose 6-phosphate and 6-phosphogluconate were reduced in multiple EGFR-mutant lung adenocarcinoma cell lines, after inhibiting the PI3K pathway with Gedatolisib (PKI-587) [12]. Additionally, PI3K/mTOR inhibition suppressed membrane localization of GLUT1, resulting in down-regulation of aerobic glycolysis [12]. In contrast to the points above, some studizes demonstrated that the mitochondria could influence signaling cascades. The expression of mutated isocitrate dehydrogenase 1 and 2 (IDH1/2) or pre-treatment with D-2-hydroxyglutarate (D2HG) impaired the differentiation of erythroleukemia cells by inhibiting 5'-methylcytosine hydroxylase Tet methylcytosine dioxygenease 2 
(TET2) [13]. Additionally, LOF mutations in succinate dehydrogenase (SDH) and fumarate hydratase (FH) have been found in paragangliomas and pheochromocytomas, and leiomas and renal cell cancer, respectively $[14,15]$. One way that high levels of succinate and fumarate may promote oncogenesis is through stabilization of Hypoxia-inducible factor 1-alpha (HIF1 $\alpha)$ and inducing a pseudohypoxic state $[16,17]$. The role of the mitochondrion in tumorigenesis is complex, as it can be influenced by upstream signaling, feedback on that signaling, or generate its own signaling.

\section{Advantages of Metabolic Reprogramming in Cancer Cells}

Normal mammalian cells rely on nutrients obtained from the extracellular environment to act as energy sources and precursors for macromolecule synthesis. Of these macromolecules, glucose can be argued to be the most important. Normal cells metabolize glucose into pyruvate that subsequently enters the TCA cycle to generate approximately 36 ATP in a process known as oxidative phosphorylation (Figure 1). The ATP generated is used to drive anabolic and catabolic reactions, vital for homeostasis and survival. Anabolic reactions involve synthesis of precursors for protein, nucleotide, and lipid synthesis. While non-proliferating cells rely on oxidative phosphorylation, rapidly proliferating cells are capable of fermenting glucose into pyruvate and then lactate, even with abundant oxygen availability, using a process termed aerobic glycolysis. There must be a benefit for rapidly dividing cells undergoing lactic fermentation in the presence of oxygen, even though it produces less ATP. The current most popular hypothesis suggests that rapidly proliferating cells, like tumor cells, use aerobic glycolysis to generate precursors for anabolic reactions synthesizing nucleic acids, lipids, and proteins [18].

\subsection{Lipid Synthesis}

To understand the benefit of aerobic glycolysis, a closer look needs to be taken at the precise role of the mitochondria in generating precursors. To do this, the mitochondria needs a continuous inflow of four carbon (4C) units to balance the outflow of $4 \mathrm{C}$ used for generation of amino acids, lipids, and nucleotides. The process of replenishing the TCA intermediates is termed anaplerosis. This process is vital for the uninterrupted turning of the TCA cycle and relies on the carboxylation of pyruvate [19-21]. In addition to $4 \mathrm{C}$, the mitochondria also need $2 \mathrm{C}$ (two carbon) units that are derived from condensation reactions with acetyl-CoA. It is important to note that there are many sources for the derivation of $2 \mathrm{C}$ units. For example, fatty acids, pyruvate, acetate, and amino acids can all be used to generate $2 \mathrm{C}$. Combining $4 \mathrm{C}$ and $2 \mathrm{C}$ units yields citrate, which can refuel the TCA cycle or exit the mitochondrion and be converted into oxaloacetate and acetyl-CoA, which will enter lipid synthesis.

Sources for cellular fatty acids (FAs) are exogenous (diet) or endogenous (anabolic biosynthesis). Homodimeric fatty acid synthase (FASN) is an enzyme responsible for catalyzing endogenous FA synthesis, using acetyl-CoA as a primer, malonyl-CoA as a $2 \mathrm{C}$ donor, and reduced nicotinamide adenine dinucleotide phosphate (NADPH) as a reducing agent. The major product of FASN is the 16C FA, palmitate [22-24]. In normal cells, FASN expression is present at low levels, as normal cells prefer to use circulating lipids for metabolic reactions, and dietary lipid intake is normally sufficient [25]. FASN is highly expressed in tissues with high levels of endogenous FA biosynthesis, like the liver, adipose tissue, and the breast [26]. Additionally, FASN expression is also found during embryogenesis, due to its role in producing lung surfactant, and the menstrual cycle as it i's associated with endometrial cell proliferation [27-29].

In tumor cells, endogenous synthesis of FAs accounts for the majority of triacylglycerol FAs, and high levels of aerobic glycolysis provide energy and precursors for FA synthesis [30,31]. The increase in FA biosynthesis may be a response to high metabolic demand of cancer cells or an adaptation to reduced availability of serum-derived lipids. In cancer cells, it is necessary to maintain a constant production of lipids to supply the high rate of membrane production and lipid-based post-translational protein modifications [32,33]. It has been demonstrated that FASN is highly expressed in bone marrow samples of patients with multiple myeloma, as demonstrated by Wang and colleagues [34]. High levels of FASN 
expression were found in 22 out of 27 tumor samples, as determined by real-time polymerase chain reaction (RT-PCR), relative to normal tissue from healthy donors. Wang's group also demonstrated that treating multiple myeloma cell lines highly expressing FASN with cerulenin, an inhibitor of FASN, inhibited its activity and induced apoptosis, suggesting that FASN can be a potential target in the treatment of multiple myeloma [34].

Several other key lipogenic enzymes can provide tumor cells with an endogenous source of FAs. ATP citrate lyase (ACLY) is an important enzyme involved in lipid biogenesis and is linked with glucose metabolism by catalyzing the conversion of citrate to oxaloacetic acid (OAA) and acetyl-CoA. High levels of ACLY expression and activity were found in lung, prostate, bladder, breast, liver, stomach, and colon cancers [30,35-40]. Interestingly, in non-small cell lung cancer, ACLY activity and over-expression was well correlated with stage, differentiation grade, and prognosis [35]. As ACLY is highly expressed in many tumor tissues, relative to healthy controls, it may be a potential drug target. Stable knockdown of ACLY in fetal liver clone 5.12 (FL5.12) cells resulted in impaired lipid synthesis, increased mitochondrial membrane potential, decreased cytokine-stimulated cell proliferation and impaired Akt-mediated tumorigenesis, in vivo [41]. Stable knockdown of ACLY induced differentiation of A549 lung adenocarcinoma and K562 chronic myelogenous leukemia cells, and suppressed tumor growth, in vivo. SB-204900, an ACLY inhibitor, induced permanent cell arrest in vitro and in vivo [42].

Another key lipogenic enzyme is acetyl-CoA carboxylase (ACACA), which is responsible for the rate limiting step of long-chain FA synthesis, because it carboxylates acetyl-CoA and produces malonyl-CoA [43]. ACACA has been shown to be over-expressed in advanced breast carcinomas and pre-neoplastic lesions that may progress to infiltrating breast carcinoma [44]. The ACACA gene was also found to be amplified in breast cancer and is associated with reduced survival [45]. Additionally, increased FA biogenesis may be associated with breast cancer in women with inherited germ line breast cancer 1, early onset (BRCA1) mutations. Recent studies found that breast-cancer-associated mutations in BRCA1 disrupt interaction between BRCA1 and phosphorylated inactivated ACACA (pACACA) [46]. Magnard et al., demonstrated that ACACA interacts with the BRCA1 C-Terminal (BRCT) domains of BRCA1 [46]. This interaction creates the BRCA1-pACACA complex, stabilizing inactive ACACA and reducing FA biogenesis. Mutations in the BRCT domain of BRCA1 (A1708E, P1749R, M1775R, R1835, Y1835) abolish this interaction. Therefore, BRCA1 with mutations affecting its BRCT domains, is unable to negatively regulate ACACA, leading to higher rates of FA synthesis. Also, it was demonstrated by Moreau et al., that BRCA1 knockdown significantly increased FA synthesis, providing evidence that BRCA1 can regulate ACACA activity, and that its tumor suppressor function may extend to regulating metabolism [47]. Additionally, the silencing of ACACA by RNAi in cell models of breast and prostate cancer impaired tumor cell proliferation and induced apoptosis, suggesting that ACACA is important for tumor cell survival $[48,49]$. Several small molecular inhibitors have been developed that target ACACA. Tofacitinib citrate (TOFA) was found to induce apoptosis in lung, colon, and breast cancer cell lines, and soraphen A induced apoptosis in prostate cancer cell lines [50-52]. These studies demonstrate the important roles of lipid biosynthesis in tumor metabolism. Further studies are needed to elucidate potential avenues for targeting these pathways, to improve patient cancer care and quality of life.

\subsection{Nucleotide Synthesis}

Rapidly proliferating cells require large amounts of purine and pyrimidine nucleotides for RNA and DNA synthesis. De novo nucleotide synthesis is complex and requires input from several pathways. The pentose phosphate pathway (PPP) provides the phosphoribosylamine backbone from ribose-5-phosphate (R5P), while glutamine is used as an amide donor [53]. Non-essential amino acids serve as precursors to purine and pyrimidine synthesis and methyl groups are obtained from the carbon (1C)/folate pool [54]. 
The Warburg effect provides cancer cells with a large influx of glycolytic intermediates, allowing tumor cells to shunt carbon from glycolysis into the PPP and synthesizing large amounts of R5P. Additionally the PPP also supplies large quantities of NADPH for detoxification of intracellular reactive oxygen species (ROS) [55]. Glucose-6-phosphate dehydrogenase (G6PD) catalyzes the first irreversible step of the PPP and generates NADPH. Due to the importance of this step, G6PD plays a critical role in regulating flux through the PPP, and high activity is expected in rapidly proliferating cells.

One of the most commonly mutated genes in cancer cells is p53, and its loss results in the enhancement of both glycolytic and PPP flux [56,57]. p53 has been found to suppress glycolysis by increasing TP53-inducible glycolysis and apoptosis regulator (TIGAR) expression and lowering intracellular levels of fructose-2,6-bisphosphate (F26BP). F26BP, being an allosteric activator of phosphofructokinase-1 (PFK1), normally increases its activity. However, when p53 is mutated and TIGAR levels are low, F26BP increases PFK1 activity and drives glycolysis [57]. Additionally, it was found that wild-type p53 is capable of inhibiting PPP by complexing with G6PD and suppressing its activity. When p53 is mutated, it loses this ability and liberates G6PD [56]. As such, p53 mutations facilitate PPP flux, allowing cancer cells to generate precursors for nucleotide synthesis. In addition to $\mathrm{p} 53$, it has also been demonstrated that mutations in K-ras ${ }^{\mathrm{G} 12 \mathrm{D}}$ stimulate glycolysis and the non-oxidative PPP, in pancreatic ductal adenocarcinoma [58].

\subsection{C Metabolism}

Another important metabolic network is the mitochondrial metabolism of $1 \mathrm{C}$ units required for purine, pyrimidine, and methionine synthesis. Folate, an essential vitamin, carries $1 \mathrm{C}$ units in its activated tetrahydrofolate form (THF). 1C metabolism plays an important role in embryogenesis, growth, development, and is required for rapidly proliferating cells. It is well known that folate deficiency during pregnancy causes neural tube defects. While major pathways for the utilization of $1 \mathrm{C}$ units are cytosolic, the mitochondria also play an important role as they contain enzymes that generate THF-bound $1 \mathrm{C}$ units.

The mitochondrial pathway can generate 1C units using many donors, like glycine and betaine [59]. It was demonstrated that mitochondrial 1C enzymes, serine hydroxymethyltransferase (SHMT2) and methylene tetrahydrofolate dehydrogenase (MTHFD2), are highly over-expressed in cancer cells $[60,61]$. SHMT1 (cytosolic) and SHMT2 (mitochondrial) are methyltransferases that convert serine to glycine. During this reaction, a $1 \mathrm{C}$ unit is transferred from serine to THF-generating methylene-THF [62]. Since serine is a non-essential amino acid, it can be generated from the glycolytic intermediate, 3-phosphoglycerate (3-PG), further suggesting that high glycolytic flux during aerobic glycolysis produces important precursors for macromolecule synthesis [63]. SHMT2 expression has been found to be elevated in myc-transformed cells and human glioblastoma tumors and promotes cancer cell survival $[64,65]$. It has been found that inhibition of serine metabolism, by serine starvation or RNAi knockdown of SHMT2, caused accumulation of precursors and inhibition of cancer cell proliferation, by depleting 1C carbon units for purine biosynthesis [65-67]. MTHFD2 is an enzyme acting downstream of SHMT2 and is responsible for the conversion of methylene-THF to formyl-THF and methyl-THF for use in nucleotide synthesis and methionine recycling. MTHFD2 was found to be expressed in embryonic, tumor, and non-differentiated tissues $[60,68]$. During the conversion, nicotinamide adenine dinucleotide phosphate (NADP+) and nicotinamide adenine dinucleotide (NAD+) are used as cofactors, producing NADPH and reduced nicotinamide adenine dinucleotide $\mathrm{NADH}$; this enables the production of reducing substances that can be used to protect the cell from ROS as well as provide reducing power for proline and fatty acid synthesis $[67,69,70]$.

Alterations in mitochondrial metabolism are common in cancer. Furthermore, high aerobic glycolysis provides precursors used by cytosolic and mitochondrial pathways to generate FA and nucleotides. It will be of interest to explore targeting these pathways for cancer therapy. 


\section{Production of Oncometabolites and Effects on Normal Metabolism: 2-Hydroxyglutarate, Succinate, and Fumarate}

Oncometabolite is a new term and refers to metabolites whose abundance is significantly increased in tumors relative to normal cells. There is now increasing evidence that oncometabolites are capable of contributing to the development and the progression of cancer. The current list of true oncometabolites is short and consists of 2-hydroxybutarate (2HG), succinate, and fumarate [71]. These oncometabolites are produced by mutations in the nuclear-encoded TCA enzymes, isocitrate dehydrogenase 1 and 2 (IDH1/2), succinate dehydrogenase (SDH), and fumarate hydratase (FH), and have been found in human cancers [72].

\subsection{Mutations Affecting Isocitrate Dehydrogenase}

There are three isoforms of IDH in human cells: IDH1 and IDH2 are homodimers that use NADP ${ }^{+}$ to catalyze the reversible conversion of isocitrate to alpha-ketoglutarate $(\alpha-\mathrm{KG})$ in the cytoplasm and the mitochondria, respectively. IDH3 is an $\mathrm{NAD}^{+}$-dependent heterotetramer that irreversibly decarboxylates isocitrate to $\alpha-K G$ in the TCA cycle [73]. While mutations have been observed in IDH1 and IDH2, IDH3 mutations have not been found in cancer. The most frequent mutations in IDH1 and IDH2 are associated with an arginine residue located in the catalytic sites, IDH1 (R132) and IDH2 (R172 or R140). These mutations have been found in human cancers, like low-grade glioma and glioblastoma, chondrosarcomas, cholangiocarcinomas, and acute myeloid leukemia (AML) [74-81].

Cancer-associated heterozygous mutations in IDH1 and IDH2 result in the formation of wild-type-mutant heterodimers with neomorphic activity, allowing the reduction of $\alpha-K G$ to 2-hydroxyglutarate (2HG) in the presence of NADPH [82-85]. This allows 2HG levels to accumulate to millimolar concentrations and exert effects on cell function (Figure 2). One example is the interference with the action of $\alpha-K G$-dependent dioxygenases ( $\alpha$ KGDD), like cytosine hydroxylases and histone demethylases $[54,86,87]$. Interestingly, while $2 \mathrm{HG}$ levels promote the hypermethylator phenotype in gliomas, known as the $\mathrm{CpG}$ island hypermethylator phenotype (CIMP), IDH1 mutations are associated with better overall survival [88-91]. Similarly, increased levels of DNA methylation were observed in AML samples with mutations in IDH1/2 or $\alpha$-KG-dependent Tet methylcytosine dioxygenease 2 (TET2), suggesting that these mutations are mutually exclusive and could be part of a common pathway [92,93]. It has been shown that D2HG can inhibit TET enzymes and supports the notion that TET inhibition and DNA hypermethylation are important for IDH-driven tumorigenesis [94]. Flavahan and colleagues provided evidence for this hypothesis by demonstrating that DNA hypermethylation at CCCTC-binding factor (CFCF) binding sites results in reduced binding and insulator activity, causing aberrant enhancer activation of platelet-derived growth factor receptor- $\alpha$ (PDGFR) in gliomas [95]. The expression of IDH1/2 mutants in erythroleukemia cells is found to inhibit differentiation and facilitate a de-differentiation phenotype [13,87]. Similar findings were observed when IDH mutants were expressed in adipocyte cell lines and resulted in inhibition of differentiation [96]. These studies suggest that $2 \mathrm{HG}$ acts as an oncogenic driver by changing epigenetic programming and inducing dedifferentiation. 2HG has also been demonstrated to inhibit prolyl-hydroxylases (PDH), an $\alpha$ KGDD, resulting in a state known as pseudohypoxia. However, there have been contradictory results as to the effect of $2 \mathrm{HG}$ on PDH and induction of a pseudohypoxic state [97]. It was demonstrated that mice with IDH1 (R132H) mutation accumulated high levels of HIF- $1 \alpha$ and upregulated HIF-1 $\alpha$ target genes $[98,99]$. Overexpression of IDH1 R132H in human embryonic kidney cells 293 (HEK293T) and human primary glioblastoma cell line (U87MG) elevated HIF-1 $\alpha$ levels [94,100]. However, this effect may be dependent on the enantiomer of 2HG, as L-2HG inhibits prolyl hydroxylase (PHD) protein activity while D-2HG promotes it, by acting as a PDH cofactor [97]. Inhibition of PDH by L-2HG increases HIF- $1 \alpha$ and causes a shift towards glycolysis and angiogenesis [101,102]. By upregulating transcription of HIF- $1 \alpha$ target genes, cancer cells increase the levels and activity of glycolytic enzymes, like hexokinase 2 (HK2) and glucose transporters (GLUT1 and GLUT3) [103]. This is important because 
HK2 is a major contributor to increased flux through glycolysis, and therefore, cells with high levels and activity of HK2 can undergo the Warburg phenotype.

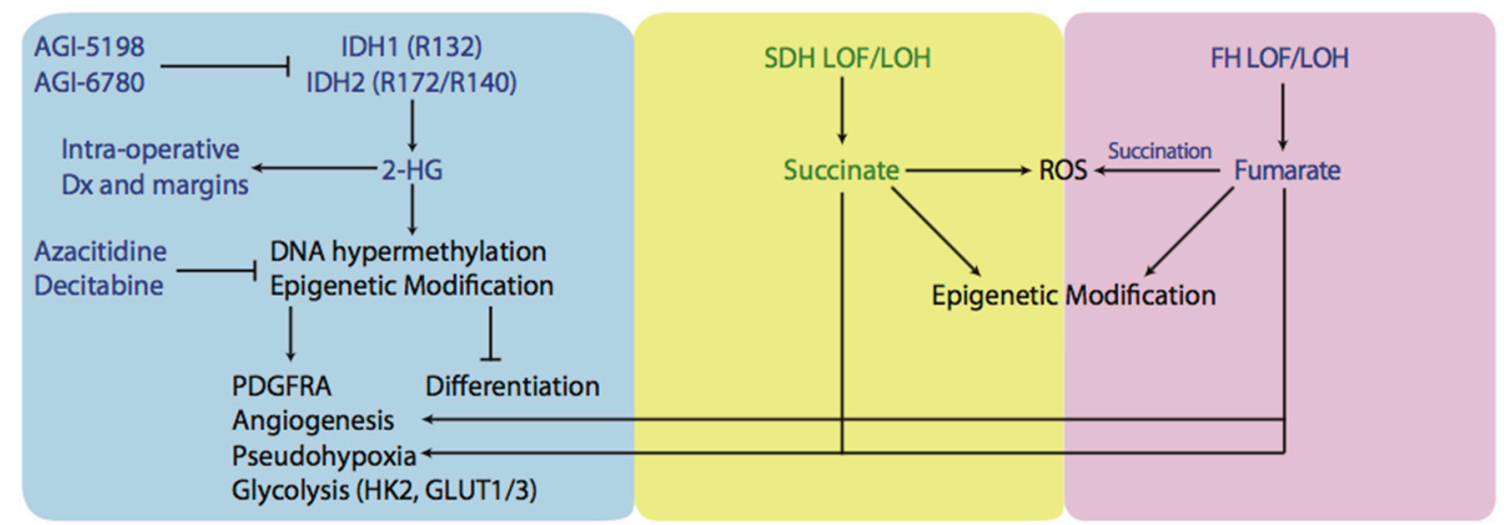

Figure 2. Schematic representation of an oncometabolic perspective of tumorigenesis. Mutated IDH1 and IDH2 produce oncometabolite known as 2-HG which goes on to exert several effects believed to trigger tumorigenesis. By inhibiting $\alpha$ KGDDs like cytosine hydroxylases, TET2, histone demethylases, IDH1/2 tumors exhibit CIMP phenotype as well as other epigenetic modifications and have inhibited differentiation. Tumours with high levels of 2-HG, succinate, or fumarate have been demonstarted to undergo a phenomenon known as pseudohypoxia and have increased levels angiogenesis. Furthermore, upregulation of HIF-1 $\alpha$ target genes like HK2 and GLUT1 and GLUT3 were found in tumours containing IDH1/2 mutations and were associated with increased rates of glycolysis. Another potential cause of tumorigenesis is the production of ROS and tumours with SDH or FH LOF or LOH have been demonstrated to have high levels of ROS. Small molecular inhibitors have been designed to target IDH1/2 mutants (AGI-5198, AGI-6780) or reverse hypermethylation levels/CIMP phenotype (azacitidine, decitabine). Furthermore, 2-HG can be detected interaoperatively during tumour resection and be used as an indication of tumor margins. IDH: isocitrate dehydrogenase; 2-HG: 2-hydroxyglutarate; $\alpha$ KGDD: $\alpha$-Ketoglutarate-dependent dioxygenases; TET2: Tet methylcytosine dioxygenase 2; CIMP: CpG island hypermethylator phenotype; HIF-1 $\alpha$ : Hypoxia-inducible factor 1-alpha; ROS: reactive oxygen species; SDH: succinate dehydrogenase; FH: fumarate hydratase; LOF: loss of function; LOH: loss of heterozygosity.

Several new therapies are being developed to target IDH-mutant tumors. Some of them belong to the class of hypomethylating agents and others belong to direct IDH mutant enzyme inhibitors. Hypomethylating agents can be used in the context of the CIMP phenotype. Azacitidine and decitabine are two examples, and they function by inhibiting DNA methyltransferase (DNMT), and demonstrated clinical benefit in myelodysplastic syndromes (MSD) and AML [104-106]. In gliomas, the use of hypomethylating agents reduced DNA methylation of promoters involved in glial cell differentiation and reduced cell proliferation in human derived IDH1 mutant glioma xenografts [107,108]. IDH mutant inhibitors, like AGI-5198 and AGI-6780, have been tested preclinically and reduced 2HG levels, reversed histone and DNA hypermethylation, and promoted cell differentiation [109-112]. Some of these inhibitors are currently being evaluated in phase I clinical trials [113].

\subsection{Mutations Affecting Succinate Dehydrogenase and Fumarate Hydratase}

The accumulation of succinate and fumarate occurs in tumors with inactivating mutations in SDH and FH enzymes. Mutations in genes of various SDH subunits have been found in paragangliomas, pheochromocytomas, and gastrointestinal stromal tumors [86,114]. Studies have identified that SDH defects account for $10-30 \%$ of sporadic paragangliomas and $10-70 \%$ of familial paragangliomas [14]. Mutations in FH genes have been found in cutaneous and uterine leiomyomatas and renal cell cancer $[15,115]$. It has been found that SDH and FH mutations follow the hereditary pattern of tumor 
suppressor genes. Affected cells inherit a germline LOF mutation in one allele and the tumors that develop exhibit loss of heterozygosity $(\mathrm{LOH})$ of the other wild-type allele, through somatic deletion or chromosomal loss [116].

There are several mechanisms that explain why LOF of SDH can lead to tumor formation (Figure 2). Similarly to $2 \mathrm{HG}$, high levels of succinate accumulate and leak out of the mitochondria via the dicarboxylate carrier and inhibit activity of HIF $\alpha$ PHDs in the cytosol, creating high levels of HIF1 $\alpha$ and inducing a pseudohypoxic response [117]. To support this hypothesis, mutations in SDH subunits D and B in tumors from families with paragangliomas were found to activate the HIF1 $\alpha$ pathway and be highly vascularized $[118,119]$. Furthermore, tumors deficient in FH also demonstrated high vascularization and significantly higher HIF1 $\alpha$ levels as well as accumulation of fumarate and succinate [120]. The accumulation of both fumarate and succinate in FH-mutated paragangliomas makes sense, as FH catalyzes the subsequent step in TCA (Figure 1).

Other than creating a pseudohypoxic environment, SDH also participates in tumorigenesis by increasing ROS levels. SDH, in addition to its role in the TCA cycle, functions as complex II of the electron transport chain (ETC) and catalyzes oxidation of succinate to fumarate, generating reduced flavin adenine dinucleotide $\left(\mathrm{FADH}_{2}\right)$, and donating its electrons to the ETC [71]. Using hepatoblastoma 3G (Hep3G) or hepatocellular carcinoma 3B (Hep3B) cells, lung carcinoma (A549) cells, and osteosarcoma cells, Guzy and colleagues demonstrated that RNA knockdown and pharmacologic inhibition of SDH-B, but not SDH-A, produced increased levels of ROS, HIF activation, and tumorigenesis [121]. Additionally, a transgenic mouse cell line (SDHC E69), overexpressing the mutated SDHC gene, was shown to overproduce the superoxide anion $\left(\mathrm{O}_{2}{ }^{-}\right)$and undergo higher rates of apoptosis. The clones that escaped apoptosis had an elevated number of DNA mutations and underwent transformation, as evidenced by the fact that cells formed benign tumors when injected into nude mice [122].

The loss of FH in renal cancer and leiomyomatosis leads to the accumulation of fumarate, and similarly to SDH loss, induces a pseudohypoxic state and accumulation of ROS [123]. To characterize FH mutations better, a database has been developed [124]. The mechanism of ROS production is different to SDH mutations. Succination is an irreversible, post-translational chemical modification of proteins formed by an addition reaction between fumarate and thiol residues [125]. High levels of fumarate can succinate glutathione, an intracellular antioxidant molecule, and reduce its antioxidant capacity [126]. NADPH, being a reducing equivalent, used in ROS detoxification, is used to metabolize the succinated glutathione. Therefore, succination of glutathione consumes NADPH and reduces the antioxidant capacity of the cell, increasing oxidative stress. Recently, it was demonstrated that succination of mitochondrial aconitase (ACO2) impairs its activity and succination of Kelch-Like ECH-associated protein-1 (KEAP1) inhibits its negative modulatory effect on nuclear factor-like 2 (NRF2) [127-129]. While NRF2 activation was previously demonstrated as a pro-tumorigenic event, its role in FH-deficient tumors remains unclear [130].

In addition to inducing a pseudohypoxic state and generating ROS, succinate and fumarate can also affect the epigenetic profile of the cell. Succinate and fumarate do this by inhibiting other $\alpha$ KGDD, like the Jumonji-C histone demethylases and the TET-family of 5-methylcytosine hydroxylases [14,131]. It was shown that knockdown of $\mathrm{FH}$ and succinate dehydrogenase complex, subunit $\mathrm{A}$ and $\mathrm{B}$ (SDHA/B) resulted in a significant increase in methylation on histone H3 Lysine 4 (H3K4), histone H3 Lysine 9 (H3K9), and histone H3 Lysine 79 (H3K79) [131]. Another study, using a human hepatocellular carcinoma G2 (HepG2) cells demonstrated that high levels of fumarate and succinate induced a loss in cell viability, activation of caspase 3/7, DNA fragmentation, and significantly increased levels of DNA hypermethylation [132].

\section{The Link between Oncometabolites and Mitochondrial Dynamics}

Metabolic derangements in cancer cells can result in increased rates of aerobic glycolysis and oxidative respiration. The production of oncometabolites has been shown to increase the invasive 
properties of cancer cells and facilitate epithelial to mesenchymal transition (EMT). Some studies have suggested a link between oncometabolites acting as paracrine signaling molecules that modulate tumor-infiltrating properties and the inflammatory response [133]. Several studies demonstrated that certain oncometabolites, like fumarate and D2HG, directly induce tumor cell migration and metastasis $[134,135]$. In addition to this, mitochondrial fragmentation has been found in invasive and metastatic tumor cells [136-139].

Mitochondrial fragmentation was previously demonstrated to be a property correlated with cell migration. It was found that mitochondria fragment and localize at the posterior regions of $\mathrm{T}$ cells, during chemotaxis. This is hypothesized to enable the mitochondria to provide energy, to facilitate migration [140,141]. Investigation into the role of mitochondrial dynamics and its role in tumorigenesis has been receiving more attention. The actions of mitochondrial-shaping proteins (OPA1, MFN1, MFN2, DRP1, FIS1) play a vital role in shaping and modifying the structure of mitochondria during fusion and division of this organelle [142]. For example, mitochondrial fragmentation has been observed during cell division in a cyclin-dependent kinase 1/dynamin-related protein 1 (CDK1/DRP1)-dependent manner in HeLa cells [143]. Another observation links mitochondrial dynamics to glycolysis, demonstrating that highly glycolytic cells have increased levels of mitochondrial fragmentation [144].

It is hypothesized that tumor metastasis is under metabolic control. This is supported by the finding that the transfer of mtDNA from highly- to weakly-metastatic cells increased their metastatic potential in mice [145]. While the exact mechanism for a mitochondrial role in metastasis is not yet clear, several studies shed light on this topic. Porporato et al., demonstrated that ETC overload and partial ETC inhibition promotes superoxide-dependent tumor cell migration and invasion [136]. Ferreira-da Silva et al., evaluated the expression of mitochondrial fusion and fission proteins in a panel of thyroid tumors and found that Drp1 overexpression was associated with migration and invasion [137]. Additionally, Drp1 expression was elevated in human invasive breast carcinoma cells that metastasized to regional lymph nodes and had higher levels of mitochondrial fragmentation, relative to non-metastatic breast cancer cells [138]. Using the human glioblastoma 251 (U251) cell model, Wan et al., demonstrated that hypoxic conditions increased Drp1 expression and facilitated mitochondrial fission, fragmentation, and tumor cell migration [139].

There is evidence for role of mitochondrial fusion and fission proteins in cell migration, invasion, and metastasis. However, there is a gap in knowledge linking oncometabolites to mitochondrial dynamics and their functional relationship with mitochondrial-shaping proteins. This represents a promising area for further study.

\section{Novel Therapies Targeting Metabolic Aberrations in Cancer Cells}

The increased understanding of molecular pathways underlying cancer progression in tumors with mutations in the TCA cycle and macromolecular synthesis enzymes has opened the door to new therapies targeted at inhibiting these pathways.

Alkylating agents, like temozolamide (TMZ), were approved in 2005 by the US Food and Drug Administration (FDA) for treatment of adult glioblastoma multiformes, along with ionizing radiation. However, tumors that express methylguanine methyltransferase (MGMT) are resistant to TMZ. Loss of MGMT expression confers sensitivity to TMZ and is often observed in tumors that have hypermethylation of the MGMT promoter. Tumors with the CIMP phenotype, previously described in this review, have been found to have higher levels of MGMT promoter hypermethylation and are more sensitive to TMZ. This can explain why IDH1/2 mutated glioblastomas and SDHB mutated paraganglioma and pheochoromocytoma are more sensitive to TMZ regiments and are associated with better prognoses [146,147].

As previously mentioned, oncometabolites may exert some of their oncogenic action by inhibiting $\alpha$ KGDDs. Therefore, reversing this dysfunction may be a promising therapeutic approach to cancers harboring these mutations. Several studies have shown that providing $\alpha-K G$ in excess can overcome the competitive inhibition of oncometabolites. High levels of $\alpha-K G$ can reverse pseudohypoxia 
and reduce the accumulation of $5 \mathrm{mC}$, in vitro. Furthermore, $\alpha-\mathrm{KG}$ demonstrated anti-tumor and anti-angiogenic properties in xenograft models by inducing PDH enzymes [148-150].

Another approach used for targeting oncometabolite pathways is to directly inhibit IDH1/2 mutants. Targeting these mutations is unique because small molecular inhibitors can inhibit IDH proteins and reduce 2-HG production. This approach has already been demonstrated and it was shown that the effects of 2-HG were reversible [13]. Additionally, Mazor et al. showed that the loss of mutant IDH1 does not completely remove the CIMP phenotype, indicating that mutant IDH1 and 2-HG may not be required for clonal expansion of glioma [151]. Inhibition of IDH2 (R140G) induced differentiation of AML cells, and inhibition of IDH1 (R132H) induced differentiation and impaired growth of glioma in in vitro and in vivo models [109,152]. Another approach to taking advantage of the IDH mutation is using is using 2-HG as a marker of tumour margins during intraoperative resection. It has been recently demonstrated that desorption electrospray ionization mass spectroscopy can detect 2-HG from tissue sections of surgically resected gliomas, intraoperatively. Levels of 2-HG correlated with tumor margins and could be mapped to 3D magnetic resonance imaging (MRI) reconstructions of tumors, allowing better localization of tumors (Figure 2). This novel approach could allow rapid molecular characterization of tissue samples during surgery and avoid the complex or time-consuming preparations associated with frozen sections [153].

\section{Conclusions}

Cancer cells can produce oncometabolites and alter normal cellular metabolic dynamics. Mutations in nuclear encoded mitochondrial enzymes can result in the production of oncometabolites, causing downstream effects. Another way that oncometabolites can be elevated is through increased flux through the TCA cycle [154]. The mitochondria are critical for oncometabolite production as well as for the increased rates of lipid and nucleotide synthesis observed in cancer cells. Two of the most studied effects of oncometabolites on cell function involve induction of a pseudohypoxic state and epigenetic regulation. However, more enzymes and pathways are likely involved and are functionally affected by oncometabolites that have not been elucidated yet. There is a growing link between oncometabolites and mitochondrial dynamics, and this is a potential exciting area of future research. Going forward, it will be important to answer the question of which metabolic pathways are drivers of cellular transformation and which are indirectly affected-passenger effects. As we understand more about the metabolic aberrations in cancer cells, due to the effect of mitochondria and oncometabolites on cancer metabolism, newer therapeutic strategies can be developed to improve cancer treatment.

Supplementary Materials: The following are available online at www.mdpi.com/2076-3921/7/1/16/s1, Table S1: Mitochondrial Genes Encoding Respiratory Chain Components.

Acknowledgments: We would like to thank Ramon Sun, Sameer Agnihotri, Stephen Amato, and Karina Chornenka for their wisdom, suggestions, and mentorship during manuscript preparation.

Conflicts of Interest: This work was supported by the University of Kentucky Center for Clinical and Translational Sciences Professional Student Mentored Research Fellowship. The National Center for Advancing Translational Sciences, UL1TR000117 (or TL1TR000115 or KL2 TR000116). Authors declare no conflicts of interests.

\section{References}

1. Cura, A.J.; Carruthers, A. Role of monosaccharide transport proteins in carbohydrate assimilation, distribution, metabolism, and homeostasis. Compr. Physiol. 2012, 2, 863-914. [PubMed]

2. Patel, M.S.; Nemeria, N.S.; Furey, W.; Jordan, F. The pyruvate dehydrogenase complexes: Structure-based function and regulation. J. Biol. Chem. 2014, 289, 16615-16623. [CrossRef] [PubMed]

3. Wallace, D.C. Mitochondria and cancer. Nat. Rev. Cancer 2012, 12, 685-698. [CrossRef] [PubMed]

4. Chinnery, P.F.; Hudson, G. Mitochondrial genetics. Br. Med. Bull. 2013, 106, 135-159. [CrossRef] [PubMed]

5. Fernandez-Vizarra, E.; Enriquez, J.A.; Perez-Martos, A.; Montoya, J.; Fernandez-Silva, P. Tissue-specific differences in mitochondrial activity and biogenesis. Mitochondrion 2011, 11, 207-213. [CrossRef] [PubMed] 
6. Farrar, G.J.; Chadderton, N.; Kena, P.F.; Millington-Ward, S. Mitochondrial disorders: Aetiologies, models systems, and candidate therapies. Trends Genet. 2013, 29, 488-497. [CrossRef] [PubMed]

7. Hanahan, D.; Weinberg, R. Hallmarks of Cancer: The Next Generation. Cell 2011, 144, 646-674. [CrossRef] [PubMed]

8. Warburg, O. On the origin of cancer cells. Science 1956, 123, 309-314. [CrossRef] [PubMed]

9. Darlington, C.D. The plasmagene theory of the origin of cancer. Br. J. Cancer 1948, 2, 118-126. [CrossRef] [PubMed]

10. Woods, M.W.; DuBuy, H.G. Cytoplasmic diseases and cancer. Science 1945, 102, 591-593. [CrossRef] [PubMed]

11. Liou, G.Y.; Döppler, H.; DelGiorno K, E.; Zhang, L.; Leitges, M.; Crawford, C.H.; Murphy, M.P.; Storz, P. Mutant Kras-induced mitochondrial oxidative stress in acinar cells upregulates EGFR signalling to drive formation of pancreatic precancerous lesions. Cell Rep. 2016, 14, 2325-2336. [CrossRef] [PubMed]

12. Makinoshima, H.; Takita, M.; Saruwatari, K.; Umemura, S.; Obata, Y.; Ishii, G.; Matsumoto, S.; Sugiyama, E.; Ochiai, A.; Abe, R.; et al. Signaling through the Phosphatidylinositol 3-Kinase (PI3K)/Mammalian Target of Rapamycin (mTOR) Axis Is Responsible for Aerobic Glycolysis mediated by Glucose Transporter in Epidermal Growth Factor Receptor (EGFR)-mutated Lung Adenocarcinoma. J. Biol. Chem. 2015, 290, 17495-17504. [CrossRef] [PubMed]

13. Losman, J.A.; Looper, R.E.; Koivunen, P.; Lee, S.; Schneider, R.K.; McMahon, C.; Cowley, G.S.; Root, D.E.; Ebert, B.L.; Kaelin, W.G., Jr. (R)-2-hydroxyglutarate is sufficient to promote leukemogenesis and its effects are reversible. Science 2013, 339, 1621-1625. [CrossRef] [PubMed]

14. Bardella, C.; Pollard, P.J.; Tomlinson, I. SDH mutations in cancer. Biochim. Biophys. Acta 2011, 1807, $1432-1443$. [CrossRef] [PubMed]

15. Picaud, S.; Kavanagh, K.L.; Yue, W.W.; Lee, W.H.; Muller-Knapp, S.; Gileadi, O.; Sacchettini, J.; Oppermann, U. Structural basis of fumarate hydratase deficienct. J. Inherit. Metab. Dis. 2011, 34, 671-676. [CrossRef] [PubMed]

16. Kurelac, I.; Romeo, C.; Gasparre, G. Mitochondrial metabolism and cancer. Mitochondrion 2010, 11, 635-637. [CrossRef] [PubMed]

17. Shanmugasundaram, K.; Nayak, B.; Shim, E.H.; Livi, C.B.; Block, K.; Sudarshan, S. The oncometabolite fumarate promotes pseudohypoxia through noncanonical activation of NF-kB signaling. J. Biol. Chem. 2014, 289, 24691-24699. [CrossRef] [PubMed]

18. Lunt, S.Y.; Vander Heiden, M.G. Aerobic glycolysis: Meeting the metabolic requirements of cell proliferation. Annu. Rev. Cell Dev. Biol. 2011, 27, 441-464. [CrossRef] [PubMed]

19. Fan, T.W.; Lane, A.N.; Higashi, R.M.; Farag, M.A.; Gao, H.; Bousamra, M.; Miller, D.M. Altered regulation of metabolic pathways is human lung cancer discerned by $13 \mathrm{C}$ stable isotope-resolved metabolomics (SIRM). Mol. Cancer 2009, 8, 41. [CrossRef] [PubMed]

20. Comerford, S.A.; Huang, Z.; Du, X.; Wang, Y.; Cai, L.; Witkiewicz, A.K.; Walters, H.; Tantawy, M.N.; Fu, A.; Manning, H.C.; et al. Acetate dependence of tumors. Cell 2014, 159, 1591-1602. [CrossRef] [PubMed]

21. DeBerardinis, R.J.; Mancuso, A.; Daikhin, E.; Nissim, I.; Yudkoff, M.; Wehrli, S.; Thompson, C.B. Beyond aerobic glycolysis: Transformed cells can engage in glutamine metabolism that exceeds the requirement for protein and nucleotide synthesis. Proc. Natl. Acad. Sci. USA 2007, 104, 19345-19350. [CrossRef] [PubMed]

22. Maier, T.; Jenni, S.; Ban, N. Architecture of mammalian fatty acid synthase at $4.5 \AA$ resolution. Science 2006, 311, 1258-1262. [CrossRef] [PubMed]

23. Asturias, F.J.; Chadick, J.Z.; Cheung, I.K.; Stark, H.; Witkowski, A.; Joshi, A.K.; Smith, S. Structure and molecular organization of mammalian fatty acid synthase. Nat. Struct. Mol. Biol. 2005, 12, 225-232. [CrossRef] [PubMed]

24. Chirala, S.S.; Wakil, S.J. Structure and function of animal fatty acid synthase. Lipids 2004, 39, 1045-1053. [CrossRef] [PubMed]

25. Weiss, L.; Hoffmann, G.E.; Schreiber, R.; Andres, H.; Fuchs, E.; Körber, E.; Kolb, H.J. Fatty-acid biosynthesis in man, a pathway of minor importance. Purification, optimal assay conditions, and organ distribution of fatty-acid synthase. Biol. Chem. Hoppe Seyler 1986, 367, 905-912. [CrossRef] [PubMed]

26. Menendez, J.A.; Lupu, R. Fatty acid synthase and the lipogenic phenotype in cancer pathogenesis. Nat. Rev. Cancer 2007, 7, 763-777. [CrossRef] [PubMed] 
27. Pizer, E.S.; Kurman, R.J.; Pasternack, G.R.; Kuhajda, F.P. Expression of fatty acid synthase is closely linked to proliferation and stromal decidualization in cycling endometrium. Int. J. Gynecol. Pathol. 1997, 16, 45-51. [CrossRef] [PubMed]

28. Kusakabe, T.; Maeda, M.; Hoshi, N.; Sugino, T.; Watanabe, K.; Fukuda, T.; Suzuki, T. Fatty acid synthase is expressed mainly in adult hormone-sensitive cells or cells with high lipid metabolism and in proliferating fetal cells. J. Histochem. Cytochem. 2000, 48, 613-622. [CrossRef] [PubMed]

29. Wagle, S.; Bui, A.; Ballard, P.L.; Shuman, H.; Gonzales, J.; Gonzales, L.W. Hormonal regulation and cellular localization of fatty acid synthase in human fetal lung. Am. J. Physiol. 1999, 277 Pt 1, L381-L390. [CrossRef] [PubMed]

30. Szutowicz, A.; Kwiatkowski, J.; Angielski, S. Lipogenetic and glycolytic enzyme activities in carcinoma and nonmalignant diseases of the human breast. Br. J. Cancer 1979, 39, 681-687. [CrossRef] [PubMed]

31. Medes, G.; Thomas, A.; Weinhouse, S. Metabolism of neoplastic tissue IV: A study of lipid synthesis in neoplastic tissue slices in vitro. Cancer Res. 1953, 13, 27-29. [PubMed]

32. Costello, L.C.; Franklin, R. Tumor cell metabolism: The marriage of molecular genetics and proteomics with cellular intermediary metabolism; proceed with caution! Mol. Cancer 2006, 5, 59. [CrossRef] [PubMed]

33. Costello, L.C.; Franklin, R. 'Why do tumour cells glycolyse?': From glycolysis through citrate to lipogenesis. Mol. Cell. Biochem. 2005, 280, 1-8. [CrossRef] [PubMed]

34. Wang, W.Q.; Zhao, X.Y.; Wang, H.Y.; Liang, Y. Increased fatty acid synthase as a potential therapeutic target in multiple myeloma. J. Zhejiang Univ. Sci. B 2008, 9, 441-447. [CrossRef] [PubMed]

35. Migita, T.; Narita, T.; Nomura, K.; Miyagi, E.; Inazuka, F.; Matsuura, M.; Ushijima, M.; Mashima, T.; Seimiya, H.; Satoh, Y.; et al. ATP citrate lyase: Activation and therapeutic implications in non-small cell lung cancer. Cancer Res. 2008, 68, 8547-8554. [CrossRef] [PubMed]

36. Yancy, H.F.; Mason, J.A.; Peters, S.; Thompson, C.E., 3rd; Littleton, G.K.; Jett, M.; Day, A.A. Metastatic progression and gene expression between breast cancer cell lines from African American and Caucasian women. J. Carcinog. 2007, 6, 8. [CrossRef] [PubMed]

37. Yahagi, N.; Shimano, H.; Hasegawa, K.; Ohashi, K.; Matsuzaka, T.; Najima, Y.; Sekiya, M.; Tomita, S.; Okazaki, H.; Tamura, Y.; et al. Co-ordinate activation of lipogenic enzymes in hepatocellular carcinoma. Eur. J. Cancer 2005, 41, 1316-1322. [CrossRef] [PubMed]

38. Varis, A.; Wolf, M.; Monni, O.; Vakkari, M.L.; Kokkola, A.; Moskaluk, C.; Frierson, H., Jr.; Powell, S.M.; Knuutila, S.; Kallioniemi, A.; et al. Targets of gene amplification and overexpression at $17 \mathrm{q}$ in gastric cancer. Cancer Res. 2002, 62, 2625-2629. [PubMed]

39. Turyn, J.; Schlichtholz, B.; Dettlaff-Pokora, A.; Presler, M.; Goyke, E.; Matuszewski, M.; Kmiec, Z.; Krajka, K.; Swierczynski, J. Increased activity of glycerol 3-phosphate dehydrogenase and other lipogenic enzymes in human bladder cancer. Horm. Metab. Res. 2003, 35, 565-569. [CrossRef] [PubMed]

40. Halliday, K.R.; Fenoglio-Preiser, C.; Sillerud, L.O. Differentiation of human tumors from nonmalignant tissue by natural-abundance 13C NMR spectroscopy. Magn. Reson. Med. 1988, 7, 384-411. [CrossRef] [PubMed]

41. Bauer, D.E.; Hatzivassiliou, G.; Zhao, F.; Andreadis, C.; Thompson, C.B. ATP citrate lyase is an important component of cell growth and transformation. Oncogene 2005, 24, 6314-6322. [CrossRef] [PubMed]

42. Hatzivassiliou, G.; Zhao, F.; Bauer, D.E.; Andreadis, C.; Shaw, A.N.; Dhanak, D.; Hingorani, S.R.; Tuveson, D.A.; Thompson, C.B. ATP citrate lyase inhibition can suppress tumor cell growth. Cancer Cell 2005, 8, 311-321. [CrossRef] [PubMed]

43. Tong, L. Acetyl-coenzyme A carboxylase: Crucial metabolic enzyme and attractive target for drug discovery. Cell. Mol. Life Sci. 2005, 62, 1784-1803. [CrossRef] [PubMed]

44. Milgraum, L.Z.; Witters, L.A.; Pasternack, G.R.; Kuhajda, F.P. Enzymes of the fatty acid synthesis pathway are highly expressed in in situ breast carcinoma. Clin. Cancer Res. 1997, 3, 2115-2120. [PubMed]

45. Chin, K.; DeVries, S.; Fridlyand, J.; Spellman, P.T.; Roydasgupta, R.; Kuo, W.L.; Lapuk, A.; Neve, R.M.; Qian, Z.; Ryder, T.; et al. Genomic and transcriptional aberrations linked to breast cancer pathophysiologies. Cancer Cell 2006, 10, 529-541. [CrossRef] [PubMed]

46. Magnard, C.; Bachelier, R.; Vincent, A.; Jaquinod, M.; Kieffer, S.; Lenoir, G.M.; Venezia, N.D. BRCA1 interacts with acetyl-CoA carboxylase through its tandem of BRCT domains. Oncogene 2002, 21, 6729-6739. [CrossRef] [PubMed] 
47. Moreau, K.; Dizin, E.; Ray, H.; Luquain, C.; Lefai, E.; Foufelle, F.; Billaud, M.; Lenoir, G.M.; Venezia, N.D. BRCA1 affects lipid synthesis through its interaction with acetyl-CoA carboxylase. J. Biol. Chem. 2006, 281, 3172-3181. [CrossRef] [PubMed]

48. Chajes, V.; Cambot, M.; Moreau, K.; Lenoir, G.M.; Joulin, V. Acetyl-CoA carboxylase alpha is essential to breast cancer cell survival. Cancer Res. 2006, 66, 5287-5294. [CrossRef] [PubMed]

49. Brusselmans, K.; De Schrijver, E.; Verhoeven, G.; Swinnen, J.V. RNA interference-mediated silencing of the acetyl-CoA-carboxylase-alpha gene induces growth inhibition and apoptosis of prostate cancer cells. Cancer Res. 2005, 65, 6719-6725. [CrossRef] [PubMed]

50. Pizer, E.S.; Thupari, J.; Han, W.F.; Pinn, M.L.; Chrest, F.J.; Frehywot, G.L.; Townsend, C.A.; Kuhajda, F.P. Malonyl-coenzyme-A is a potential mediator of cytotoxicity induced by fatty-acid synthase inhibition in human breast cancer cells and xenografts. Cancer Res. 2000, 60, 213-218. [PubMed]

51. Wang, C.; Xu, C.; Sun, M.; Luo, D.; Liao, D.F.; Cao, D. Acetyl-CoA carboxylase-alpha inhibitor TOFA induces human cancer cell apoptosis. Biochem. Biophys. Res. Commun. 2009, 385, 302-306. [CrossRef] [PubMed]

52. Beckers, A.; Organe, S.; Timmermans, L.; Scheys, K.; Peeters, A.; Brusselmans, K.; Verhoeven, G.; Swinnen, J.V. Chemical inhibition of acetyl-CoA carboxylase induces growth arrest and cytotoxicity selectively in cancer cells. Cancer Res. 2007, 67, 8180-8187. [CrossRef] [PubMed]

53. Stincone, A.; Prigione, A.; Cramer, T.; Wamelink, M.M.; Campbell, K.; Cheung, E.; Olin-Sandoval, V.; Grüning, N.M.; Krüger, A.; Tauqeer Alam, M.; et al. The return of metabolism: Biochemistry and physiology of the pentose phosphate pathway. Biol. Rev. Camb. Philos. Soc. 2016, 90, 927-963. [CrossRef] [PubMed]

54. DeBerardinis, R.J.; Chandel, N.S. Fundamentals of cancer metabolism. Sci. Adv. 2016, 2, e1600200. [CrossRef] [PubMed]

55. Agnihotri, S.; Zadeh, G. Metabolic reprogramming in glioblastoma: The influence of cancer metabolism on epigenetics and unanswered questions. Neuro-Oncology 2016, 18, 160-172. [CrossRef] [PubMed]

56. Jiang, P.; Du, W.; Wang, X.; Mancuso, A.; Gao, X.; Wu, M.; Yang, X. p53 Regulates Biosynthesis through Direct Inactivation of Glucose-6-Phosphate Dehydrogenase. Nat. Cell Biol. 2011, 13, 310-316. [CrossRef] [PubMed]

57. Bensaad, K.; Tsuruta, A.; Selak, M.A.; Vidal, M.N.; Nakano, K.; Bartrons, R.; Gottlieb, E.; Vousden, K.H. TIGAR, a p53-inducible regulator of glycolysis and apoptosis. Cell 2006, 126, 107-120. [CrossRef] [PubMed]

58. Ying, H.; Kimmelman, A.C.; Lyssiotis, C.A.; Hua, S.; Chu, G.C.; Fletcher-Sananikone, E.; Locasale, J.W.; Son, J.; Zhang, H.; Coloff, J.L.; et al. Oncogenic Kras maintains pancreatic tumors through regulation of anabolic glucose metabolism. Cell 2012, 149, 656-670. [CrossRef] [PubMed]

59. Locasale, J.W. Serine, glycine and one-carbon units: Cancer metabolism in full circle. Nat. Rev. Cancer 2013, 13, 572-583. [CrossRef] [PubMed]

60. Nilsson, R.; Jain, M.; Madhusudhan, N.; Sheppard, N.G.; Strittmatter, L.; Kampf, C.; Huang, J.; Asplund, A.; Mootha, V.K. Metabolic enzyme expression highlights a key role for MTHFD2 and the mitochondrial folate pathway in cancer. Nat. Commun. 2014, 5, 3128. [CrossRef] [PubMed]

61. Vazquez, A.; Tedeschi, P.M.; Bertino, J.R. Overexpression of the mitochondrial folate and glycine-serine pathway: A new determinant of methotrexate selectivity in tumors. Cancer Res. 2013, 73, 478-482. [CrossRef] [PubMed]

62. Tibbetts, A.S.; Appling, D.R. Compartmentalization of Mammalian folate-mediated one-carbon metabolism. Annu. Rev. Nutr. 2010, 30, 57-81. [CrossRef] [PubMed]

63. Yang, M.; Vousden, K.H. Serine and one-carbon metabolism in cancer. Nat. Rev. Cancer 2016, 16, 650-662. [CrossRef] [PubMed]

64. Ye, J.; Fan, J.; Venneti, S.; Wan, Y.W.; Pawel, B.R.; Zhang, J.; Finley, L.W.; Lu, C.; Lindsten, T.; Cross, J.R.; et al. Serine catabolism regulates mitochondrial redox control during hypoxia. Cancer Discov. 2014, 4, 1406-1417. [CrossRef] [PubMed]

65. Kim, D.; Fiske, B.P.; Birsoy, K.; Freinkman, E.; Kami, K.; Possemato, R.L.; Chudnovsky, Y.; Pacold, M.E.; Chen, W.W.; Cantor, J.R.; et al. SHMT2 drives glioma cell survival in ischaemia but imposes a dependence on glycine clearance. Nature 2015, 520, 363-367. [CrossRef] [PubMed]

66. Labuschagne, C.F.; van den Broek, N.J.; Mackay, G.M.; Vousden, K.H.; Maddocks, O.D. Serine, but not glycine, supports one-carbon metabolism and proliferation of cancer cells. Cell Rep. 2014, 7, 1248-1258. [CrossRef] [PubMed] 
67. Ducker, G.S.; Chen, L.; Morscher, R.J.; Ghergurovich, J.M.; Esposito, M.; Teng, X.; Kang, Y.; Rabinowitz, J.D. Reversal of Cytosolic One-Carbon Flux Compensates for Loss of the Mitochondrial Folate Pathway. Cell Metab. 2016, 23, 1140-1153. [CrossRef] [PubMed]

68. Bolusani, S.; Young, B.A.; Cole, N.A.; Tibbetts, A.S.; Momb, J.; Bryant, J.D.; Solmonson, A.; Appling, D.R. Mammalian MTHFD2L encodes a mitochondrial methylenetetrahydrofolate dehydrogenase isozyme expressed in adult tissues. J. Biol. Chem. 2011, 286, 5166-5174. [CrossRef] [PubMed]

69. Meiser, J.; Tumanov, S.; Maddocks, O.; Labuschagne, C.F.; Athineos, D.; Van Den Broek, N.; Mackay, G.M.; Gottlieb, E.; Blyth, K.; Vousden, K.; et al. Serine one-carbon catabolism with formate overflow. Sci. Adv. 2016, 2, e1601273. [CrossRef] [PubMed]

70. Lewis, C.A.; Parker, S.J.; Fiske, B.P.; McCloskey, D.; Gui, D.Y.; Green, C.R.; Vokes, N.I.; Feist, A.M.; Vander Heiden, M.G.; Metallo, C.M. Tracing compartmentalized NADPH metabolism in the cytosol and mitochondria of mammalian cells. Mol. Cell 2014, 55, 253-263. [CrossRef] [PubMed]

71. Yang, M.; Soga, T.; Pollard, P.J. Oncometabolites: Linking altered metabolism with cancer. J. Clin. Investig. 2013, 123, 3652-3658. [CrossRef] [PubMed]

72. Gaude, E.; Frezza, C. Defects in mitochondrial metabolism and cancer. Cancer Metab. 2014, 2, 10. [CrossRef] [PubMed]

73. Frezza, C.; Pollard, P.J.; Gottlieb, E. Inborn and acquired metabolic defects in cancer. J. Mol. Med. (Berl.) 2011, 89, 213-220. [CrossRef] [PubMed]

74. Mardis, E.R.; Ding, L.; Dooling, D.J.; Larson, D.E.; McLellan, M.D.; Chen, K.; Koboldt, D.C.; Fulton, R.S.; Delehaunty, K.D.; McGrath, S.D.; et al. Recurring mutations found by sequencing an acute myeloid leukemia genome. N. Engl. J. Med. 2009, 361, 1058-1066. [CrossRef] [PubMed]

75. Thompson, C.B. Metabolic enzymes as oncogenes or tumor suppressors. N. Engl. J. Med. 2009, 360, 813-815. [CrossRef] [PubMed]

76. Amary, M.F.; Bacsi, K.; Maggiani, F.; Damato, S.; Halai, D.; Berisha, F.; Pollock, R.; O’Donnell, P.; Grigoriadis, A.; Diss, T.; et al. IDH1 and IDH2 mutations are frequent events in central chondrosarcoma and central and periosteal chondromas but not in other mesenchymal tumours. J. Pathol. 2011, 224, 334-343. [CrossRef] [PubMed]

77. Borger, D.R.; Tanabe, K.K.; Fan, K.C.; Lopez, H.U.; Fantin, V.R.; Straley, K.S.; Schenkein, D.P.; Hezel, A.F.; Ancukiewicz, M.; Liebman, H.M.; et al. Frequent mutation of isocitrate dehydrogenase (IDH)1 and IDH2 in cholangiocarcinoma identified through broad-based tumor genotyping. Oncologist 2012, 17, 72-79. [CrossRef] [PubMed]

78. Oermann, E.K.; Wu, J.; Guan, K.L.; Xiong, Y. Alterations of metabolic genes and metabolites in cancer. Semin. Cell Dev. Biol. 2012, 23, 370-380. [CrossRef] [PubMed]

79. Yan, H.; Parsons, D.W.; Jin, G.; McLendon, R.; Rasheed, B.A.; Yuan, W.; Kos, I.; Batinic-Haberle, I.; Jones, S.; Riggins, G.J.; et al. IDH1 and IDH2 mutations in gliomas. N. Engl. J. Med. 2009, 360, 765-773. [CrossRef] [PubMed]

80. Parsons, D.W.; Jones, S.; Zhang, X.; Lin, J.C.; Leary, R.J.; Angenendt, P.; Mankoo, P.; Carter, H.; Siu, I.M.; Gallia, G.L.; et al. An integrated genomic analysis of human glioblastoma multiforme. Science 2008, 321, 1807-1812. [CrossRef] [PubMed]

81. Yang, H.; Ye, D.; Guan, K.L.; Xiong, Y. IDH1 and IDH2 mutations in tumorigenesis: Mechanistic insights and clinical perspectives. Clin. Cancer Res. 2012, 18, 5562-5571. [CrossRef] [PubMed]

82. Ward, P.S.; Patel, J.; Wise, D.R.; Abdel-Wahab, O.; Bennett, B.D.; Coller, H.A.; Cross, J.R.; Fantin, V.R.; Hedvat, C.V.; Perl, A.E.; et al. The common feature of leukemia-associated IDH1 and IDH2 mutations is a neomorphic enzyme activity converting alpha-ketoglutarate to 2-hydroxyglutarate. Cancer Cell 2010, 17, 225-234. [CrossRef] [PubMed]

83. Dang, L.; White, D.W.; Gross, S.; Bennett, B.D.; Bittinger, M.A.; Driggers, E.M.; Fantin, V.R.; Jang, H.G.; Jin, S.; Keenan, M.C.; et al. Cancer-associated IDH1 mutations produce 2-hydroxyglutarate. Nature 2010, 465, 966. [CrossRef] [PubMed]

84. Gross, S.; Cairns, R.A.; Minden, M.D.; Driggers, E.M.; Bittinger, M.A.; Jang, H.G.; Jang, H.G.; Sasaki, M.; Jin, S.; Schenkein, D.P.; Su, S.M.; et al. Cancer-associated metabolite 2-hydroxyglutarate accumulates in acute myelogenous leukemia with isocitrate dehydrogenase 1 and 2 mutations. J. Exp. Med. 2010, 207, 339-344. [CrossRef] [PubMed] 
85. Leonardi, R.; Subramanian, C.; Jackowski, S.; Rock, C.O. Cancer-associated isocitrate dehydrogenase mutations inactivate NADPH-dependent reductive carboxylation. J. Biol. Chem. 2012, 287, 14615-14620. [CrossRef] [PubMed]

86. Jochmanova, I.; Pacak, K. Pheochromocytoma: The First Metabolic Endocrine Cancer. Clin. Cancer Res. 2016, 22, 5001-5011. [CrossRef] [PubMed]

87. Sciacovelli, M.; Frezza, C. Oncometabolites: Unconventional triggers of oncogenic signalling cascades. Free Radic. Biol. Med. 2016, 100, 175-181. [CrossRef] [PubMed]

88. Noushmehr, H.; Weisenberger, D.J.; Diefes, K.; Phillips, H.S.; Pujara, K.; Berman, B.P.; Pan, F.; Pelloski, C.E.; Sulman, E.P.; Bhat, K.P.; et al. Identification of a CPG island methylator phenotype that defines a distinct subgroup of glioma. Cancer Cell 2010, 17, 510-522. [CrossRef] [PubMed]

89. Turcan, S.; Rohle, D.; Goenka, A.; Walsh, L.A.; Fang, F.; Yilmaz, E.; Campos, C.; Fabius, A.W.; Lu, C.; Ward, P.S.; et al. IDH1 mutation is sufficient to establish the glioma hypermethylator phenotype. Nature 2012, 483, 479-483. [CrossRef] [PubMed]

90. Ohgaki, H.; Burger, P.; Kleihues, P. Definition of primary and secondary glioblastoma-Response. Clin. Cancer Res. 2014, 20, 2013. [CrossRef] [PubMed]

91. Ohgaki, H.; Kleihues, P. Genetic pathways to primary and secondary glioblastoma. Am. J. Pathol. 2007, 170, 1445-1453. [CrossRef] [PubMed]

92. Figueroa, M.E.; Abdel-Wahab, O.; Lu, C.; Ward, P.S.; Patel, J.; Shih, A.; Li, Y.; Bhagwat, N.; Vasanthakumar, A.; Fernandez, H.F.; et al. Leukemic IDH1 and IDH2 mutations result in a hypermethylation phenotype, disrupt TET2 function, and impair hematopoietic differentiation. Cancer Cell 2010, 18, 553-567. [CrossRef] [PubMed]

93. Delhommeau, F.; Dupont, S.; Della Valle, V.; James, C.; Trannoy, S.; Masse, A.; Kosmider, O.; Le Couedic, J.P.; Robert, F.; Alberdi, A.; et al. Mutation in TET2 in myeloid cancers. N. Engl. J. Med. 2009, 360, 2289-2301. [CrossRef] [PubMed]

94. Xu, W.; Yang, H.; Liu, Y.; Yang, Y.; Wang, P.; Kim, S.H.; Ito, S.; Yang, C.; Wang, P.; Xiao, M.T.; et al. Oncometabolite 2-hydroxyglutarate is a competitive inhibitor of alpha-ketoglutarate-dependent dioxygenases. Cancer Cell 2011, 19, 17-30. [CrossRef] [PubMed]

95. Flavahan, W.A.; Drier, Y.; Liau, B.B.; Gillespie, S.M.; Venteicher, A.S.; Stemmer-Rachamimov, A.O.; Suva, M.L.; Bernstein, B.E. Insulator dysfunction and oncogene activation in IDH mutant gliomas. Nature 2016, 529, 110-114. [CrossRef] [PubMed]

96. Lu, C.; Ward, P.S.; Kapoor, G.S.; Rohle, D.; Turcan, S.; Abdel-Wahab, O.; Edwards, C.R.; Khanin, R.; Figueroa, M.E.; Melnick, A.; et al. IDH mutation impairs histone demethylation and results in a block to cell differentiation. Nature 2012, 483, 474-478. [CrossRef] [PubMed]

97. Koivunen, P.; Lee, S.; Duncan, C.G.; Lopez, G.; Lu, G.; Ramkissoon, S.; Losman, J.A.; Joensuu, P.; Bergmann, U.; Gross, S.; et al. Transformation by the (R)-enantiomer of 2-hydroxyglutarate linked to EGLN activation. Nature 2012, 483, 484-488. [CrossRef] [PubMed]

98. Sasaki, M.; Knobbe, C.B.; Itsumi, M.; Elia, A.J.; Harris, I.S.; Chio, I.I.; Cairns, R.A.; McCracken, S.; Wakeham, A.; Haight, J.; et al. D-2-hydroxyglutarate produced by mutant IDH1 perturbs collagen maturation and basement membrane function. Genes Dev. 2012, 26, 2038-2049. [CrossRef] [PubMed]

99. Sasaki, M.; Knobbe, C.B.; Munger, J.C.; Lind, E.F.; Brenner, D.; Brustle, A.; Harris, I.S.; Holmes, R.; Wakeham, A.; Haight, J.; et al. IDH1(R132H) mutation increases murine haematopoietic progenitors and alters epigenetics. Nature 2012, 488, 656-659. [CrossRef] [PubMed]

100. Zhao, S.; Lin, Y.; Xu, W.; Jiang, W.; Zha, Z.; Wang, P.; Yu, W.; Li, Z.; Gong, L.; Peng, Y.; et al. Glioma-derived mutations in IDH1 dominantly inhibit IDH1 catalytic activity and induce HIF-1alpha. Science 2009, 324, 261-265. [CrossRef] [PubMed]

101. Brat, D.J.; Mapstone, T.B. Malignant glioma physiology: Cellular response to hypoxia and its role in tumor progression. Ann. Intern. Med. 2003, 138, 659-668. [CrossRef] [PubMed]

102. Wang, G.L.; Jiang, B.H.; Rue, E.A.; Semenza, G.L. Hypoxia-inducible factor 1 is a basic-helix-loop-helix-PAS heterodimer regulated by cellular $\mathrm{O} 2$ tension. Proc. Natl. Acad. Sci. USA 1995, 92, 5510-5514. [CrossRef] [PubMed]

103. Semenza, G.L. Targeting HIF-1 for cancer therapy. Nat. Rev. Cancer 2003, 3, 721-732. [CrossRef] [PubMed] 
104. Fenaux, P.; Mufti, G.J.; Hellstrom-Lindberg, E.; Santini, V.; Gattermann, N.; Germing, U.; Sanz, G.; List, A.F.; Gore, S.; Seymour, J.F.; et al. Azacitidine prolongs overall survival compared with conventional care regimens in elderly patients with low bone marrow blast count acute myeloid leukemia. J. Clin. Oncol. 2010, 28, 562-569. [CrossRef] [PubMed]

105. Kantarjian, H.M.; Thomas, X.G.; Dmoszynska, A.; Wierzbowska, A.; Mazur, G.; Mayer, J.; Gau, J.P.; Chou, W.C.; Buckstein, R.; Cermak, J.; et al. Multicenter, randomized, open-label, phase III trial of decitabine versus patient choice, with physician advice, of either supportive care or low-dose cytarabine for the treatment of older patients with newly diagnosed acute myeloid leukemia. J. Clin. Oncol. 2012, 30, 2670-2677. [CrossRef] [PubMed]

106. Dombret, H.; Seymour, J.F.; Butrym, A.; Wierzbowska, A.; Selleslag, D.; Jang, J.H.; Kumar, R.; Cavenagh, J.; Schuh, A.C.; Candoni, A.; et al. International phase 3 study of azacitidine vs. conventional care regimens in older patients with newly diagnosed AML with $>30 \%$ blasts. Blood 2015, 126, 291-299. [CrossRef] [PubMed]

107. Borodovsky, A.; Salmasi, V.; Turcan, S.; Fabius, A.W.; Baia, G.S.; Eberhart, C.G.; Weingart, J.D.; Gallia, G.L.; Baylin, S.B.; Chan, T.A.; et al. 5-azacytidine reduces methylation, promotes differentiation and induces tumor regression in a patient-derived IDH1 mutant glioma xenograft. Oncotarget 2013, 4, 1737-1747. [CrossRef] [PubMed]

108. Turcan, S.; Fabius, A.W.; Borodovsky, A.; Pedraza, A.; Brennan, C.; Huse, J.; Viale, A.; Riggins, G.J.; Chan, T.A.; et al. Efficient induction of differentiation and growth inhibition in IDH1 mutant glioma cells by the DNMT Inhibitor Decitabine. Oncotarget 2013, 4, 1729-1736. [CrossRef] [PubMed]

109. Wang, F.; Travins, J.; DeLaBarre, B.; Penard-Lacronique, V.; Schalm, S.; Hansen, E.; Straley, K.; Kernytsky, A.; Liu, W.; Gliser, C.; et al. Targeted inhibition of mutant IDH2 in leukemia cells induces cellular differentiation. Science 2013, 340, 622-626. [CrossRef] [PubMed]

110. Kernytsky, A.; Wang, F.; Hansen, E.; Schalm, S.; Straley, K.; Gliser, C.; Yang, H.; Travins, J.; Murray, S.; Dorsch, M.; et al. IDH2 mutation-induced histone and DNA hypermethylation is progressively reversed by small-molecule inhibition. Blood 2015, 125, 296-303. [CrossRef] [PubMed]

111. Quivoron, C.; David, M.; Straley, K.; Travins, J.; Kim, H.; Chen, Y.; Zhu, D.; Saada, V.; Bawa, O.; Opolon, P.; et al. AG-221, an oral, selective, first-in-class, potent IDH2-R140Q mutant inhibitor, induces differentiation in a Xenotransplant Model. Blood 2014, 124, 3735.

112. Hansen, E.; Quivoron, C.; Straley, K.; Lemieux, R.M.; Popovici-Muller, J.; Sadrzadeh, H.; Fathi, A.T.; Gliser, C.; David, M.; Saada, V.; et al. AG-120, an oral, selective, first-in-class, potent inhibitor of mutant IDH1, reduces intracellular 2HG and induces cellular differentiation in TF-1 R132H cells and primary human IDH1 mutant AML patient samples treated Ex Vivo. Blood 2014, 124, 3734.

113. Mondesir, J.; Willekens, C.; Touat, M.; de Botton, S. IDH1 and IDH2 mutations as novel therapeutic targets: Current perspectives. J. Blood Med. 2016, 7, 171-180. [PubMed]

114. Miettinen, M.; Lasota, J. Succinate dehydrogenase deficient gastrointestinal stromal tumors (GISTs) - A review. Int. J. Biochem. Cell Biol. 2014, 53, 514-519. [CrossRef] [PubMed]

115. Lehtonen, H.J.; Kiuru, M.; Ylisaukko-Oja, S.K.; Salovaara, R.; Herva, R.; Koivisto, P.A.; Vierimaa, O.; Aittomaki, K.; Pukkala, E.; Launonen, V.; et al. Increased risk of cancer in patients with fumarate hydratase germline mutation. J. Med. Genet. 2006, 43, 523-526. [CrossRef] [PubMed]

116. Bayley, J.P.; Devilee, P. Warburg tumours and the mechanisms of mitochondrial tumour suppressor genes. Barking up the right tree? Curr. Opin. Genet. Dev. 2010, 20, 324-329. [CrossRef] [PubMed]

117. Selak, M.A.; Armour, S.M.; MacKenzie, E.D.; Boulahbel, H.; Watson, D.G.; Mansfield, K.D.; Pan, Y.; Simon, M.C.; Thompson, C.B.; Gottlieb, E. Succinate links TCA cycle dysfunction to oncogenesis by inhibiting HIF-alpha prolyl hydroxylase. Cancer Cell 2005, 7, 77-85. [CrossRef] [PubMed]

118. Gimenez-Roqueplo, A.P.; Favier, J.; Rustin, P.; Rieubland, C.; Kerlan, V.; Plouin, P.F.; Rotig, A.; Jeunemaitre, X. Functional consequences of a SDHB gene mutation in an apparently sporadic pheochromocytoma. J. Clin. Endocrinol. Metab. 2002, 87, 4771-4774. [CrossRef] [PubMed]

119. Gimenez-Roqueplo, A.P.; Favier, J.; Rustin, P.; Mourad, J.J.; Plouin, P.F.; Corvol, P.; Rotig, A.; Jeunemaitre, X. The R22X mutation of the SDHD gene in hereditary paraganglioma abolishes the enzymatic activity of complex II in the mitochondrial respiratory chain and activates the hypoxia pathway. Am. J. Hum. Genet. 2001, 69, 1186-1197. [CrossRef] [PubMed] 
120. Pollard, P.J.; Briere, J.J.; Alam, N.A.; Barwell, J.; Barclay, E.; Wortham, N.C.; Hunt, T.; Mitchell, M.; Olpin, S.; Moat, S.J.; et al. Accumulation of Krebs cycle intermediates and over-expression of HIF1alpha in tumours which result from germline FH and SDH mutations. Hum. Mol. Genet. 2005, 14, 2231-2239. [CrossRef] [PubMed]

121. Guzy, R.D.; Sharma, B.; Bell, E.; Chandel, N.S.; Schumacker, P.T. Loss of the SdhB, but Not the SdhA, subunit of complex II triggers reactive oxygen species-dependent hypoxia-inducible factor activation and tumorigenesis. Mol. Cell. Biol. 2008, 28, 718-731. [CrossRef] [PubMed]

122. Ishii, T.; Yasuda, K.; Akatsuka, A.; Hino, O.; Hartman, P.S.; Ishii, N. A mutation in the SDHC gene of complex II increases oxidative stress, resulting in apoptosis and tumorigenesis. Cancer Res. 2005, 65, 203-209. [PubMed]

123. Sudarshan, S.; Sourbier, C.; Kong, H.S.; Block, K.; Valera Romero, V.A.; Yang, Y.; Galindo, C.; Mollapour, M.; Scroggins, B.; Goode, N.; et al. Fumarate hydratase deficiency in renal cancer induces glycolytic addiction and hypoxia-inducible transcription factor 1alpha stabilization by glucose-dependent generation of reactive oxygen species. Mol. Cell. Biol. 2009, 29, 4080-4090. [CrossRef] [PubMed]

124. Bayley, J.P.; Launonen, V.; Tomlinson, I.P. The FH mutation database: An online database of fumarate hydratase mutations involved in the MCUL (HLRCC) tumor syndrome and congenital fumarase deficiency. BMC Med. Genet. 2008, 9, 20. [CrossRef] [PubMed]

125. Blatnik, M.; Thorpe, S.R.; Baynes, J.W. Succination of proteins by fumarate: Mechanism of inactivation of glyceraldehyde-3-phosphate dehydrogenase in diabetes. Ann. N. Y. Acad. Sci. 2008, 1126, 272-275. [CrossRef] [PubMed]

126. Sullivan, L.B.; Martinez-Garcia, E.; Nguyen, H.; Mullen, A.R.; Dufour, E.; Sudarshan, S.; Licht, J.D.; Deberardinis, R.J.; Chandel, N.S. The proto-oncometabolite fumarate binds glutathione to amplify ROS-dependent signaling. Mol. Cell 2013, 51, 236-248. [CrossRef] [PubMed]

127. Adam, J.; Hatipoglu, E.; O’Flaherty, L.; Ternette, N.; Sahgal, N.; Lockstone, H.; Baban, D.; Nye, E.; Stamp, G.W.; Wolhuter, K.; et al. Renal cyst formation in Fh1-deficient mice is independent of the Hif/Phd pathway: Roles for fumarate in KEAP1 succination and Nrf2 signaling. Cancer Cell 2011, 20, 524-537. [CrossRef] [PubMed]

128. Ternette, N.; Yang, M.; Laroyia, M.; Kitagawa, M.; O’Flaherty, L.; Wolhulter, K.; Igarashi, K.; Saito, K.; Kato, K.; Fischer, R.; et al. Inhibition of mitochondrial aconitase by succination in fumarate hydratase deficiency. Cell Rep. 2013, 3, 689-700. [CrossRef] [PubMed]

129. Ooi, A.; Wong, J.C.; Petillo, D.; Roossien, D.; Perrier-Trudova, V.; Whitten, D.; Min, B.W.; Tan, M.H.; Zhang, Z.; Yang, X.J.; et al. An antioxidant response phenotype shared between hereditary and sporadic type 2 papillary renal cell carcinoma. Cancer Cell 2011, 20, 511-523. [CrossRef] [PubMed]

130. DeNicola, G.M.; Karreth, F.A.; Humpton, T.J.; Gopinathan, A.; Wei, C.; Frese, K.; Mangal, D.; Yu, K.H.; Yeo, C.J.; Calhoun, E.S.; et al. Oncogene-induced Nrf2 transcription promotes ROS detoxification and tumorigenesis. Nature 2011, 475, 106-109. [CrossRef] [PubMed]

131. Xiao, M.; Yang, H.; Xu, W.; Ma, S.; Lin, H.; Zhu, H.; Liu, L.; Liu, Y.; Yang, C.; Xu, Y.; et al. Inhibition of alpha-KG-dependent histone and DNA demethylases by fumarate and succinate that are accumulated in mutations of FH and SDH tumor suppressors. Genes Dev. 2012, 26, 1326-1338. [CrossRef] [PubMed]

132. Wentzel, J.F.; Lewies, A.; Bronkhorst, A.J.; van Dyk, E.; du Plessis, L.H.; Pretorius, P.J. Exposure to high levels of fumarate and succinate leads to apoptotic cytotoxicity and altered global DNA methylation profiles in vitro. Biochimie 2017, 135, 28-34. [CrossRef] [PubMed]

133. Corrado, M.; Scorrano, L.; Campello, S. Changing perspective on oncometabolites: From metabolic signature of cancer to tumorigenic and immunosuppressive agents. Oncotarget 2016, 7, 46692-46706. [CrossRef] [PubMed]

134. Janin, M.; Esteller, M. Oncometabolite Accumulation and Epithelial-to-Mesenchymal Transition: The Turn of Fumarate. Cell Metab. 2016, 24, 529-530. [CrossRef] [PubMed]

135. Colvin, H.; Nishida, N.; Konno, M.; Haraguchi, N.; Takahashi, H.; Nishimura, J.; Hata, T.; Kawamoto, K.; Asai, A.; Tsunekuni, K.; et al. Oncometabolite D-2-Hydroxyglurate Directly Induces Epithelial-Mesenchymal Transition and is Associated with Distant Metastasis in Colorectal Cancer. Sci. Rep. 2016, 6, 36289. [CrossRef] [PubMed]

136. Porporato, P.E.; Payen, V.L.; Perez-Escuredo, J.; De Saedeleer, C.J.; Danhier, P.; Copetti, T.; Dhup, S.; Tardy, M.; Vazeille, T.; Bouzin, C.; et al. A mitochondrial switch promotes tumor metastasis. Cell Rep. 2014, 8, 754-766. [CrossRef] [PubMed] 
137. Ferreira-da-Silva, A.; Valacca, C.; Rios, E.; Populo, H.; Soares, P.; Sobrinho-Simoes, M.; Scorrano, L.; Maximo, V.; Campello, S. Mitochondrial dynamics protein Drp1 is overexpressed in oncocytic thyroid tumors and regulates cancer cell migration. PLoS ONE 2015, 10, e0122308. [CrossRef] [PubMed]

138. Zhao, J.; Zhang, J.; Yu, M.; Xie, Y.; Huang, Y.; Wolff, D.W.; Abel, P.W.; Tu, Y. Mitochondrial dynamics regulates migration and invasion of breast cancer cells. Oncogene 2013, 32, 4814-4824. [CrossRef] [PubMed]

139. Wan, Y.Y.; Zhang, J.F.; Yang, Z.J.; Jiang, L.P.; Wei, Y.F.; Lai, Q.N.; Wang, J.B.; Xin, H.B.; Han, X.J. Involvement of Drp1 in hypoxia-induced migration of human glioblastoma U251 cells. Oncol. Rep. 2014, 32, 619-626. [CrossRef] [PubMed]

140. Campello, S.; Lacalle, R.A.; Bettella, M.; Manes, S.; Scorrano, L.; Viola, A. Orchestration of lymphocyte chemotaxis by mitochondrial dynamics. J. Exp. Med. 2006, 203, 2879-2886. [CrossRef] [PubMed]

141. Da Silva, A.F.; Mariotti, F.R.; Maximo, V.; Campello, S. Mitochondria dynamism: Of shape, transport and cell migration. Cell. Mol. Life Sci. 2014, 71, 2313-2324. [CrossRef] [PubMed]

142. Corrado, M.; Scorrano, L.; Campello, S. Mitochondrial dynamics in cancer and neurodegenerative and neuroinflammatory diseases. Int. J. Cell Biol. 2012, 2012, 729290. [CrossRef] [PubMed]

143. Taguchi, N.; Ishihara, N.; Jofuku, A.; Oka, T.; Mihara, K. Mitotic phosphorylation of dynamin-related GTPase Drp1 participates in mitochondrial fission. J. Biol. Chem. 2007, 282, 11521-11529. [CrossRef] [PubMed]

144. Hackenbrock, C.R. Ultrastructural bases for metabolically linked mechanical activity in mitochondria. I. Reversible ultrastructural changes with change in metabolic steady state in isolated liver mitochondria. J. Cell Biol. 1966, 30, 269-297. [CrossRef] [PubMed]

145. Ishikawa, K.; Takenaga, K.; Akimoto, M.; Koshikawa, N.; Yamaguchi, A.; Imanishi, H.; Nakada, K.; Honma, Y.; Hayashi, J. ROS-generating mitochondrial DNA mutations can regulate tumor cell metastasis. Science 2008, 320, 661-664. [CrossRef] [PubMed]

146. Hadoux, J.; Favier, J.; Scoazec, J.Y.; Leboulleux, S.; Al Ghuzlan, A.; Caramella, C.; Deandreis, D.; Borget, I.; Loriot, C.; Chougnet, C.; et al. SDHB mutations are associated with response to temozolomide in patients with metastatic pheochromocytoma or paraganglioma. Int. J. Cancer 2014, 135, 2711-2720. [CrossRef] [PubMed]

147. SongTao, Q.; Lei, Y.; Si, G.; YanQing, D.; HuiXia, H.; XueLin, Z.; LanXiao, W.; Fei, Y. IDH mutations predict longer survival and response to temozolomide in secondary glioblastoma. Cancer Sci. 2012, 103, 269-273. [CrossRef] [PubMed]

148. Briere, J.J.; Favier, J.; Benit, P.; El Ghouzzi, V.; Lorenzato, A.; Rabier, D.; Di Renzo, M.F.; Gimenez-Roqueplo, A.P.; Rustin, P. Mitochondrial succinate is instrumental for HIF1alpha nuclear translocation in SDHA-mutant fibroblasts under normoxic conditions. Hum. Mol. Genet. 2005, 14, 3263-3269. [CrossRef] [PubMed]

149. Letouze, E.; Martinelli, C.; Loriot, C.; Burnichon, N.; Abermil, N.; Ottolenghi, C.; Janin, M.; Menara, M.; Nguyen, A.T.; Benit, P.; et al. SDH mutations establish a hypermethylator phenotype in paraganglioma. Cancer Cell 2013, 23, 739-752. [CrossRef] [PubMed]

150. Matsumoto, K.; Obara, N.; Ema, M.; Horie, M.; Naka, A.; Takahashi, S.; Imagawa, S. Antitumor effects of 2-oxoglutarate through inhibition of angiogenesis in a murine tumor model. Cancer Sci. 2009, 100, 1639-1647. [CrossRef] [PubMed]

151. Mazor, T.; Chesnelong, C.; Pankov, A.; Jalbert, L.E.; Hong, C.; Hayes, J.; Smirnov, I.V.; Marshall, R.; Souza, C.F.; Shen, Y.; et al. Clonal expansion and epigenetic reprogramming following deletion or amplification of mutant IDH1. Proc. Natl. Acad. Sci. USA 2017, 114, 10743-10748. [CrossRef] [PubMed]

152. Rohle, D.; Popovici-Muller, J.; Palaskas, N.; Turcan, S.; Grommes, C.; Campos, C.; Tsoi, J.; Clark, O.; Oldrini, B.; Komisopoulou, E.; et al. An inhibitor of mutant IDH1 delays growth and promotes differentiation of glioma cells. Science 2013, 340, 626-630. [CrossRef] [PubMed]

153. Santagata, S.; Eberlin, L.S.; Norton, I.; Calligaris, D.; Feldman, D.R.; Ide, J.L.; Liu, X.; Wiley, J.S.; Vestal, M.L.; Ramkissoon, S.H.; et al. Intraoperative mass spectrometry mapping of an onco-metabolite to guide brain tumor surgery. Proc. Natl. Acad. Sci. USA 2014, 111, 11121-11126. [CrossRef] [PubMed]

154. Hensley, C.T.; Faubert, B.; Yuan, Q.; Lev-Cohain, N.; Jin, E.; Kim, J.; Jiang, L.; Ko, B.; Skelton, R.; Loudat, L.; et al. Metabolic Heterogeneity in Human Lung Tumors. Cell 2016, 164, 681-694. [CrossRef] [PubMed]

(C) 2018 by the authors. Licensee MDPI, Basel, Switzerland. This article is an open access article distributed under the terms and conditions of the Creative Commons Attribution (CC BY) license (http:/ / creativecommons.org/licenses/by/4.0/). 